\title{
THE TREATMENT OF SUBFERTILE MEN WITH CLOMIPHENE CITRATE
}

\author{
G. L. FOSS, V. R. TINDALL* AND J. P. BIRKETT \\ Bristol Male Subfertility Clinic, Professorial Unit, Cardiff University, and \\ Richardson Merrell Limited
}

(Received 17th August 1972)

\begin{abstract}
Summary. In a double-blind clinical trial, 114 subfertile men were given courses of clomiphene citrate $(100 \mathrm{mg}$ daily for three 10-day periods in successive months) and of placebo tablets of identical appearance. There were no consistent changes in sperm density. No serious adverse reactions to clomiphene were seen. Further studies are recommended on the efficacy of clomiphene in doses of 25 to $50 \mathrm{mg}$ daily for periods of 60 to 90 days.
\end{abstract}

Clomiphene citrate, a synthetic non-steroidal compound, inhibits gonadotrophins and has an antifertility effect in rodents (Holtkamp, Davis \& Rhoads, 1961) yet stimulates ovulation in a high proportion of anovulatory infertile women (Bishop, 1970; Anon., 1968; Kistner, 1966). In women, clomiphene's effect is probably achieved by first stimulating gonadotrophin release from the pituitary which, in turn, stimulates ovulation (Heller \& Moore, 1963).

Clomiphene causes increased gonadotrophin and oestrogen excretion both in premenopausal females (Loraine, 1966) and in 'normal' males (Harkness, Loraine, Bell \& Morse, 1964). In males, urinary 17-keto-steroids (Harkness et al., 1964) and testosterone (Harkness, Loraine, Bell \& Ismail, 1965) levels are also increased.

Glinical studies on the effects of clomiphene in subfertile men have produced variable results but higher sperm counts have been seen in most cases (Jungck, Roy, Greenblatt \& Mahesh, 1964; Mellinger \& Thompson, 1966; Potts, 1968); the different dosages and the duration of treatment and of follow-up may explain some of the apparent discrepancies (Heller, Rowley \& Heller, 1969).

The object of the study reported in this paper was to examine the effects of clomiphene in subfertile men in a controlled double-blind trial.

For 3 years at two centres, one in Bristol and one in Cardiff, men attending with subfertility were invited to join this trial. A complete history had been taken and a clinical examination had been carried out on all patients, and at least two analyses of semen were arranged, usually at intervals of a week and following 2 or 3 days of continence. The inability of the patients' wives to conceive in the absence of any physical abnormality in themselves was a primary criterion of their husbands' subfertility, which was assessed before and after 'treatment' by a comparison of the highest total sperm counts. Motility was an

* Present address: Department of Obstetrics, University of Manchester. 
impossible parameter to assess because the intervals between the collection of specimens and their examination at the laboratory were too variable. Reports of morphological changes in the spermatozoa were found from experience to vary with the subjective assessments of different pathologists, and therefore to be impossible to correlate.

Testicular biopsies, and chromosomal or hormonal studies, if performed, were carried out before the trial began but were not repeated. The wives of all the patients had been investigated and no abnormality had been found.

In this double-blind trial, supplies of clomiphene and placebo tablets were prepared by the manufacturers and coded individually so that the same number of patients were given active or placebo tablets first.

Table 1. Numbers of subfertile men at two centres receiving treatment with clomiphene citrate and/or a placebo

\begin{tabular}{l|c|c|c|c}
\hline & $\begin{array}{c}\text { Total } \\
\text { no. of } \\
\text { patients }\end{array}$ & $\begin{array}{c}\text { No. of patients } \\
\text { receiving active } \\
\text { and placebo } \\
\text { tablets }\end{array}$ & $\begin{array}{c}\text { No. of patients } \\
\text { receiving active } \\
\text { tablets only }\end{array}$ & $\begin{array}{c}\text { No. of patients } \\
\text { receiving placebo } \\
\text { tablets only }\end{array}$ \\
\hline Bristol & 50 & 42 & 6 & 2 \\
Cardiff & 64 & 53 & 7 & 4 \\
\hline Total & 114 & 95 & 13 & 6 \\
\hline
\end{tabular}

Table 2. The highest pretreatment total sperm count recorded for subfertile men subsequently treated with clomiphene citrate and/or a placebo and the number of impregnations recorded following treatment

\begin{tabular}{|c|c|c|c|c|c|}
\hline & \multicolumn{4}{|c|}{ Total sperm count } & \multirow{2}{*}{$\begin{array}{c}\text { Total } \\
\text { no. } \\
\text { of men }\end{array}$} \\
\hline & $\begin{array}{l}\text { Below } \\
10 \times 10^{6}\end{array}$ & $\begin{array}{r}10 \text { to } 20 \\
\times 10^{6}\end{array}$ & $\begin{array}{c}20 \text { to } 30 \\
\times 10^{6}\end{array}$ & $\begin{array}{c}\text { Above } 30 \\
\times 10^{6}\end{array}$ & \\
\hline $\begin{array}{l}\text { No. of men } \\
\text { Bristol } \\
\text { Cardiff } \\
\text { Total }\end{array}$ & $\begin{array}{c}4 \\
24 \\
28 *\end{array}$ & $\begin{array}{r}7 \\
10 \\
17\end{array}$ & $\begin{array}{l}4 \\
5 \\
9\end{array}$ & $\begin{array}{l}35 \\
25 \\
60\end{array}$ & $\begin{array}{r}50 \\
64 \\
114\end{array}$ \\
\hline Impregnations & 3 & 3 & 2 & 11 & 19 \\
\hline
\end{tabular}

* Including fifteen azoospermic men, none of whom showed an improved sperm count or achieved impregnation.

One treatment consisted of three 10-day courses, at monthly intervals, of two 50 -mg tablets daily of clomiphene or of two placebo tablets of identical appearance and comparable taste. After completing 3 consecutive months of taking one preparation, patients were entered again into the trial, usually after a further interval of 3 months, when they were given the alternative preparation. Patients were reviewed at monthly intervals throughout the trial period and, at longer intervals, for up to 2 years thereafter. Sperm counts were assessed during and after the trial. A specially prepared record card was completed for each patient and all the results were analysed by an independent observer. 
A total of 114 patients entered the trial (Table 1); ninety-five had courses of both active and placebo tablets; thirteen received active tablets only and six received placebo tablets only. The results showing the highest pretreatment total sperm counts and the number of pregancies reported following treatment are summarized in Table 2. The inclusion of the data of impregnations in this table cannot be taken as reliable evidence for the effect of the treatment.

The average age of the patients was 30.6 years, ranging from 20 to 45 years. The average duration of marriage of the patients was $6 \frac{1}{2}$ years, ranging from 2 to 16 years.

One patient had diabetes, five had histories of mumps (two in childhood), one of rubella (as an adult), one of gonorrhoea, one of genito-urinary tuberculosis with excision of one testis; three had surgical repairs of varicocoeles and two others had small untreated varicocoeles, one had a hydrocoele repaired surgically and three had had an inguinal hernia repaired in childhood.

Testicular biopsies from thirty-one patients showed normal spermatogenesis in ten patients, depressed spermatogenesis in eleven, tubular atrophy in seven and thickening or hyalinization of the basement membrane in three. The chromosomal and hormonal studies carried out did not reveal any abnormalities.

There were no serious side-effects recorded during the trial but of six minor side effects reported, three occurred during courses of placebo tablets and three while active clomiphene was being taken. One patient reported increased libido when taking placebo tablets, another complained of irritability and the third of soreness/discomfort in the chest. While taking active clomiphene, one patient complained of dizziness, one of abdominal discomfort and one of mouth ulcers and a rash.

From the results of this trial using the dosage recorded, it was not possible to confirm or refute the hypothesis that clomiphene may be effective in the treatment of some subfertile men. As other workers have reported, the results show that men with azoospermia are unlikely to respond to treatment.

From studies on normal men, Heller et al. (1969) showed that, with some individual variations, low dosages of clomiphene (50 mg daily) stimulated spermatogenesis whereas higher doses (200 to $400 \mathrm{mg}$ daily) usually depressed it. These workers also found that, although a substantial increase in the excretion of urinary gonadotrophins occurred within 2 or 3 weeks of daily doses of $50 \mathrm{mg}$ clomiphene, no improvement in sperm count occurred until 2 or 3 months had elapsed and an optimal response was sometimes recorded 3 to 12 months later. Jungck et al. (1964) also reported that $50 \mathrm{mg}$ clomiphene daily for 8 weeks improved spermatogenesis in patients with oligospermia and two of their patients who apparently failed to respond did show significant improvement 1 to 3 months later.

A patient with Klinefelter's syndrome and a 47 XXY karyotype, reported by Foss, Bell, Lewis, Loraine \& Pollard (1967) received several courses of clomiphene over a period of 17 weeks. After remission of treatment for 30 weeks during which azoospermia was observed, a short course of clomiphene consisting of $100 \mathrm{mg}$ daily for 7 days was given while hormone assays were carried out. On the 3 rd day of treatment, a semen specimen containing $18 \times 10^{6}$ spermatozoa 
with $60 \%$ motility was obtained. It was suggested that clomiphene might act directly on enzyme systems in the testis to prevent spermatid degeneration.

It is possible that the dose of clomiphene used in the study reported here was too high and also that the duration of the courses of treatment was too short; the time interval for a possible alteration in the function of the germinal epithelium to be reflected in the ejaculate is known to be at least 60 and up to as long as 90 days (Heller et al., 1969).

In future studies, clomiphene will be given to subfertile men in doses of 25 $\mathrm{mg}$ or $50 \mathrm{mg}$ daily for periods of 8 to 12 weeks. Since the trial ended, seven of the men previously included in it have been given courses of $50 \mathrm{mg}$ clomiphene daily for up to 90 days and three of their wives have become pregnant.

\section{REFERENGES}

Anon. (1968) Glomiphene citrate. Br. med. F. i, 363.

Bisнop, P. M. F. (1970) Clomiphene. Br. med. Bull. 26, 22.

Foss, G. L., Bell, E. T., Lewis, F. J. W., Loraine, J. A. \& Pollard, B. R. (1967) The effect of clomiphene on spermatogenesis and hormone excretion in a patient with Klinefelter's syndrome. F. Reprod. Fert. 13, 315.

Harkness, R. A., Loraine, J. A., Bell, E. T. \& Ismail, A. (1965) The effect of clomiphene on steroid and gonadotrophin excretion by human subjects. F. Reprod. Fert. 10, 289.

Harkness, R. A., Loraine, J. A., Bell, E. T. \& Morse, W. I. (1964) The effect of clomiphene on endocrine function in normal man. F. Endocr. 31, 53.

Heller, C. G. \& MoORE, D. J. (1963) Dichotomy between total gonadotrophins (HPG) and IGSH excretion produced by clomiphene. Clin. Res. 11, 111.

Heller, C. G., Rowley, N. J. \& Heller, G. V. (1969) Clomiphene citrate: a correlation of its effect on sperm concentration and morphology, total gonadotrophins, ICSH, estrogen and testosterone excretion and testicular cytology in normal men. F. clin. Endocr. Metab. 29, 638.

Holtkamp, D. E., Davis, R. H. \& Rhoads, J. E. (1961) Effect of chloramiphene on fertility and ovulation. Fedn Proc. Fedn Am. Socs exp. Biol. 20, 419.

Jungck, E. G., Roy, S., Greenblatt, R. B. \& Mahesh, V. B. (1964) Effect of clomiphene citrate on spermatogenesis in the human. A preliminary report. Fert. Steril. 15, 40.

KISTNER, R. W. (1966) Use of clomiphene citrate, human chorionic gonadotropin and human menopausal gonadotropin for induction of ovulation in the human female. Fert. Steril. 17, 569.

LoRAine, J. A. (1966) The effect of clomiphene (MRL-41) on hormone excretion in human subjects. Proc. R. Soc. Med. 59, 28.

Mellinger, R. C. \& Thompson, R. J. (1966) The effect of clomiphene citrate in male infertility. Fert. Steril. 17, 94.

PotTs, I. F. (1968) A clinical evaluation of two types of therapy for male infertility: ligation of varicocele and 'clomid'. Med. F. Aust. i, 707. 